\title{
KNOWLEDGE MANAGEMENT AND TRANSFER: THE ROLE OF CUISINE IN TRANSFERRING CULTURAL KNOWLEDGE
}

\author{
Fred Hoffman, Robert Morris University, fphst122@mail.rmu.edu \\ Brett Kempf, Robert Morris University, bwkst676@mail.rmu.edu \\ Alvi Lim, Robert Morris University, awlst313@mail.rmu.edu
}

\begin{abstract}
Both food and the rituals and practices associated with its preparation, presentation, and consumption have consistently played a core role in developing, defining, and sustaining cultural identity. Not only are certain cooking styles and individual dishes emblematic of particular cultures, but the history, traditions, and rituals associated with the preparation, presentation, and consumption of those distinctive dishes serve to instill in members what it means to be part of a certain cultural group. Culture consists of both explicit and tacit forms of knowledge, and the successful transfer of both types of knowledge is critical for the sustainment of a culture from one generation to the next. Through the sharing of distinctive, food-related experiences, older members of a culture transfer some defining characteristics of that culture with younger members, who internalize those experiences and expand their own tacit knowledge of what it means to be a member of that culture. The SECI model, originally developed by Nonaka and Takeuchi (1995) to examine how knowledge is shared and created within corporations, is used here to illuminate how four different types of knowledge transfer have been employed by three distinct cultures to define and sustain their respective cultures through food and food-related rituals.
\end{abstract}

Keywords: Knowledge Management, Cuisine, Transfer of Knowledge, Food, Culture.

\section{INTRODUCTION}

To someone raised and socialized within a particular culture, one of the most readily-identifiable symbols of that culture will invariably be its cuisine. Within a cultural context, cuisine is far more than simply the various food dishes themselves; cuisine also encompasses the rituals, practices, and taboos associated with gathering ingredients and then preparing, presenting, and consuming the various dishes. Within a particular culture, some of those traditions may have deep religious or historical roots. Over time, comprehensive knowledge of the cuisine associated with one's culture is transferred to young members of the culture through a variety of means. While some aspects of that body of cuisine-related cultural knowledge are more easily articulated and transferred than others, other aspects can only be acquired through repetitive, personal experience over time. While the Chinese, French, and Russian cultures each have distinctive cuisines, an examination of these three different cuisines reveals identifiable methods used in each culture to preserve and effectively transfer cuisine-related knowledge within the culture.

\section{FOOD AND CULTURE}

Anthropologist Clifford Geertz describes culture as "semiotic", based on "webs of significance" created by the members of a cultural group (Geertz, 1973, p. 5). Culture, says Geertz (1973), "consists of socially-established structures of meaning" (p. 12), and is a "context" in which its observable attributes can be "thickly described" (p. 14). According to Geertz (1973), "it is through the flow of behavior - or, more precisely, social action - that cultural forms find articulation" (p. 17). Geertz (1973) states that culture is comprised of "symbolic acts or clusters of symbolic acts" (p. 26). Like Geertz (1973), Geert Hofstede (2010) also takes a semiotic approach to studying culture, and acknowledges the importance of symbols, heroes, ritual, and values, which he labels the "four manifestations of culture" (Hofstede, 2010, p 7). Hofstede (2010) also notes that food is one of the basic "ingredients" of culture, dating back to the bands of hunter-gatherers. "Everybody's contribution was needed in order to provide food" (p. 439). 


\section{Issues in Information Systems \\ Volume 19, Issue 1, pp. 159-169, 2018}

While food served as a shared survival need and focus for primitive cultures, as those cultures evolved, so did the role played by food within those cultures. "In a primitive society, a daily ritual is incorporated in common activities, in eating, washing, fire-making, etc., as well as in pure ceremonial; because the need of reasserting the tribal morale and recognizing its cosmic conditions is constantly felt" (Geertz, 1973, p. 99). A variety of converging forces shaped and sustained ancient cultures over time. Religion and legal tradition, for example, played a major role in the development and sustainment of ancient cultures that arose in Egypt, Israel, Greece, Rome, India, Tibet, China, and Japan (Piwowarski, 2013). These religious and legal traditions influenced thinking within the culture with respect to behavior, dress, and food - not only forming traditions related to all three, but also forming social taboos (Minkov, 2012). As a result of food-centered social rituals, Geertz observes, "neighborhood solidarity is strengthened" (p. 147). Holak (2014) asserts that food "is central to cultural identity" (p. 188).

Consistent with Geertz's semiotic approach to studying culture, Blackledge (2017) asserts that one can learn a lot about a culture by taking note of its food culture:

The meaning of different foods, the rituals of their production and consumption, our attitudes towards them, our treatment and choice of them vary dramatically from culture to culture, from society to society. Being deeply embedded in our social practices, foods can tell us much about cultural, social and economic relations. Thus, understanding food culture and food politics means, to a large extent, understanding the culture and the society in which such ways are practiced (Blackledge, 2017, p. 198).

Geertz (1973) described the key roles played by food, and food-related behaviors, in a particular culture following his groundbreaking cultural research on the Indonesian island of Java. "It is not just to eat; it is to prefer certain foods cooked in certain ways and to follow a rigid table etiquette in consuming them" (Geertz, 1973, p. 53). Geertz describes a traditional Javanese communal feast called the slametan:

Slametans, which are given with only slight variations in form and content on almost all occasions of religious significance-at passage points in the life cycle, on calendrical holidays, at certain stages of the crop cycle, on changing one's residence, and so on-are intended to be both offerings to the spirits and commensal mechanisms of social integration for the living. The meal, which consists of specially prepared dishes, each symbolic of a particular religious concept, is cooked by the female members of one nuclear family household and set out on mats in the middle of the living room. The male head of the household invites the male heads of the eight or ten contiguous households to attend; no closer neighbor is ignored in favor of one farther away. After a speech by the host explaining the spiritual purpose of the feast and a short Arabic chant, each man takes a few hurried, almost furtive, gulps of food, wraps the remainder of the meal in a banana-leaf basket, and returns home to share it with his family (Geertz, 1973, p. 147).

Vujačić \& Kovačević (2016) observe that "food determines the identity of people: from diverse social identities (ethnic, class, religious) to personal identity, which includes questions of attitude and personal taste. The issue of nutrition becomes a question of the attitude towards oneself and towards the world and not merely the issue of selfpreservation" (p. 98-99). Because food is "associated with many customs and rituals", it "has become a cultural activity", its preparation "approaches art", and within a given culture, food serves "as a communicative form of culture” (Vujačić \& Kovačević, 2016, p. 98).

With respect to social norms, attitudes, and behaviors, Hofstede (2010) notes, "Parents tend to reproduce the education that they received, whether they want to or not" (p. 11). One of the ways parents (and other family members) reproduce their own cultural education is with respect to food, where they pass on attitudes, traditions, rituals, and taboos that they themselves had acquired within the culture.

\section{TACIT AND EXPLICIT KNOWLEDGE}

According to Polanyi (1966), knowledge is either explicit or tacit. Explicit knowledge is easily articulated and can be rapidly and comprehensively transferred to others; examples include facts, words, numbers, diagrams, and other symbols (Morgan, n.d., p. 3). By contrast, tacit knowledge is more complex, and not easily articulated or rapidly transferred. The challenge associated with transferring tacit knowledge, as Polanyi (1966) famously observed, is that 
"we can know more than we can tell" (p. 4). Tacit knowledge transfer commonly involves some degree of physical action and firsthand experience by the recipient of the knowledge; frequently-mentioned examples of tacit knowledge acquisition include learning how to ride a bicycle, or play soccer (Polanyi, 1966). National cultures consist of both explicit and tacit knowledge, and successfully transferring both forms of knowledge within the group is essential for a culture to sustain itself from one generation to the next.

\section{CULTURAL KNOWLEDGE TRANSFER}

\section{SECI Model}

One oft-cited theoretical construct used to explain how explicit and tacit information is shared within groups is the SECI Model, created by Nonaka and Takeuchi (1995) to describe how knowledge is both transferred and created within organizations. Although our focus here is on cultures (rather than corporations) and food (rather than finance), the four elements of the SECI model provide a useful lens with which to examine the transfer of explicit and tacit knowledge within cultural groups. The SECI acronym derives from the names Nonaka and Takeuchi assigned to their four different modes of knowledge transfer: socialization (tacit $\rightarrow$ tacit knowledge transfer), externalization (tacit $\rightarrow$ explicit), combination (explicit $\rightarrow$ explicit), and internalization (explicit $\rightarrow$ tacit).

Figure 1 lists the SECI Model that was developed by Nonaka and Takeuchi (1995).

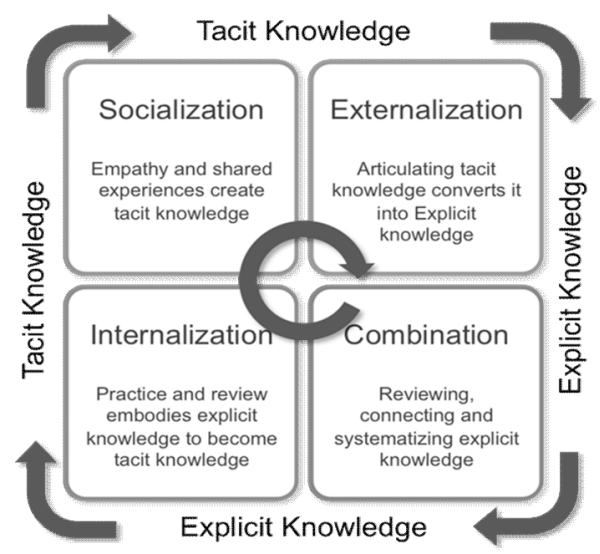

Figure 1. Spiral of Knowledge (SECI Model) (Adapted from Nonaka \& Takeuchi, 1995)

\section{THE SECI MODEL AND CULTURAL KNOWLEDGE TRANSFER THROUGH CUISINE}

Through cuisine itself, and through its associated customs, rituals, symbols, and practices, cultural knowledge is passed on from generation to generation in various ways that can be explained by the SECI model. Because tacit knowledge is difficult to articulate, and resistant to rapid transfer, the tacit-to-tacit transfer of cultural knowledge is achieved through socialization, such as when Chinese chef apprentices acquire their skills over time by observing and mimicking master chefs, or when Russian children regularly accompany their parents into the woods to pick wild mushrooms for inclusion in a certain dish, gradually learning over time how to distinguish edible from poisonous varieties. Tacit knowledge was transformed into explicit knowledge when experienced French chefs engaged in externalization documenting and disseminating in cookbooks for the masses the recipes they had perfected over the course of a lifetime, thus making that precious knowledge readily available to a far wider audience. When Russian families took the original recipe for Olivier salad and adapted it to Russian tastes, conditions, and ingredient availability, they aggregated explicit knowledge from different sources, thus engaging in combination by merging disparate bits of explicit knowledge to create something new and uniquely Russian. Finally, 


\section{Issues in Information Systems \\ Volume 19, Issue 1, pp. 159-169, 2018}

and perhaps most critically from an enculturation standpoint, participation of members of all three cultures in the various traditions and rituals associated with food preparation, presentation, and consumption exemplified internalization, that is, transforming repeated, explicit experiences into highly personalized knowledge based on firsthand experience, what Polanyi (1966) characterizes as tacit knowledge.

\section{French Cuisine}

The term French cuisine can invoke images of haute cuisine in downtown Paris, just as it can conjure up a meal made from scratch in the French countryside. Meals now associated with modern French cuisine range from food popularized by the working class to dishes originally only served in private quarters, dishes that were once equally appreciated as a spectacle as they were for their flavor (Ferguson, 1998). French cuisine as described in the $17^{\text {th }}$ and $18^{\text {th }}$ century was associated with aristocracy, not the society (Ferguson, 1998). It was not until French cuisine spread to the masses did what we now think of as French cuisine became popularized for those outside of nobility. This transformation of French cuisine is widely attributed to two chefs who not only refined traditional recipes but also documented them. Rather than keeping these techniques guarded amongst personal networks passed along solely by oral communication, these cookbooks, along with culinary critiques during the $19^{\text {th }}$ century, enabled recipes and culture to move forward to modern times (Ferguson, 1998).

Food refers to the material substances we humans consume to meet the physiological requirements for sustenance; food is what we eat to live. Cooking begins the primary transformative process that puts food in a state ready to be consumed. But if cooking involves chiefly the producer of the dish, gastronomy (a new term in nineteenth-century Paris) points to the sophisticated diner, to the embodiment of BrillatSavarin's ideal consumer: "Animals fill themselves, people eat, intelligent people alone know how to eat. (Ferguson, 2006)

French gastronomy, the art and science of cooking, was modernly constructed through the recording of recipes in texts and the distribution of them to other chefs, critiquing and writing about food, and the public awareness of these recipes (Ferguson, 1998). Cuisine is the combination of a culinary process intermingled with culture, referencing the society it's a part of (Clark, 1975). "Cuisine, like dining, turns the private into the public, the singular into the collective, the material into the cultural" (Ferguson, 2006).

Marie-Antoine Carême and Georges Auguste Escoffier are widely credited as popularizing and updating French cuisine from a largely ostentatious affair to the modern and elegant meals we now envision. Carême's style of streamlining and treating meals and Escoffier's later refinement, making these already restrained meals less sophisticated, made recipes more accessible and easier to replicate.

Pampille assigns "national" status to some dishes that cut across class as well as region-pot-au-feu (boiled beef), onion soup, chicken soup, cabbage soup, leek and potato soup, potato salad, chicken fricassée, stews, omelets. These are the foods of peasant and bourgeois alike. Professional training has little to do with making these dishes what they are. The "poor fisherman" on the Mediterranean coast prepares bouillabaisse quite as well as the "cleverest Marseilles chef." The local becomes the national, with the result that to taste one of the four soup "poems" is to partake of what is most authentically French. The part and the whole coincide. (Ferguson, 2010)

Carême disparaged the old cuisine of the ancien régime because it did not mesh with the zeitgeist of postrevolutionary France, and in his Philosophical History of Cuisine (1833), Carême took the idea of chef as artist from ancien régime cuisine and created a vision of grande cuisine as both an art and a science. He simplified meals so that there were four courses at dinner instead of eight, gave more space to those persons sitting at the table, and sought to redefine humble dishes such as the pot au feu as the essence of a modern cuisine. (Rao, Monin, \& Durand, 2003)

Food is constantly changing. Culinary habits travel with groups and communities as they move to new areas and bring their rituals with them (Ferguson, 2010). The changing of France's culture during “...the social and economic transformation of post-Revolutionary France permitted the elaboration of gastronomy, which, however, would not have been possible without the legacy of the pre-Revolutionary cuisine and its associations with the aristocracy." 


\section{Issues in Information Systems \\ Volume 19, Issue 1, pp. 159-169, 2018}

(Clark, 1975). In the nineteenth century, after Carême's innovations and refinements, did French cuisine come to stand for France (Ferguson, 2006).

Carême had a disdain for excessive spices, incorporating herbs instead of the over spiced cuisine he saw as excessive and extravagant (Ferguson, 2003). His books used words that were mostly untranslatable due to being technical and like other sciences, deduced from other languages (Ferguson, 2003) "Like ballet, cuisine would continue to speak French" (Ferguson, 2003). It was this initial association that "French cuisine has long drawn great strength from its capacity to translate the exotic into familiar terms" (Ferguson, 2010).

Ferguson (2003) illustrates the importance of recording the recipes in text rather than communicating through the personal connections and oral networks. Carême still prepared meals for the wealthy but recorded his recipes in his books rather than communicate within a largely oral culture which his predecessors did (Ferguson, 1998).

Until the 1970s, the elite cuisine of France was a structured and organized system of gastronomy. Many dishes were interrelated, and their names contained clues as to their ingredients. For example, soups were broken down into consommes' (clear soups), potages (thick soups), cremes (cream 'soups), and veloutes (made with a white sauce). ' Within each of these categories, there were subcategories, depending upon the base used, the thickening agent, the garniture, the flavoring spice, herb, or alcohol, and other considerations. This structured classical cuisine was codified in Escoffier's cookbooks - notably Le Guide Culinaire (1903), in which he formalized classical French cuisine in its modern form, setting down thousands of menus and clarifying the principles of French gastronomy" (Escoffier, 1903/1993). (Durand, Rao, \& Monin, 2007)

\section{Chinese Cuisine}

The saying: "We do not know a nation until we sit at its dining table" (Qin, 2013, p. 35) comes to mind for those who have experienced Chinese culture, or are of Chinese descent. Food is rich with tradition and meaning within the Chinese community. The central role played by food within the Chinese culture is demonstrated by the way some Chinese greet one another. Rather than employ the common greeting of "How are you?", Chinese commonly greet friends and acquaintances with the question, "Have you eaten?" This practice is not only common throughout China, but also in the many communities of overseas Chinese scattered around the globe. Kirkendall (2010) commented that most "traditional gastronomic behavior within a particular culture is subject to changes that can be internally or externally generated" but the "Chinese ethnogastronomy seems to prevail as a tradition wherever Chinese people live" (p. 123).

Chinese cuisine provides an eating experience where all five human senses can be experienced in a single meal. The delicate, multi-sensory presentation of Chinese dishes on the dining table makes one's mouth water in anticipation; the touch of the crunchy pork-skin dish adds to the sensation of the body; the smell of the aura stimulates the nose; and the taste whets the appetite of the tongue. Just like the "clink" sound of the champagne glasses to produce the fifth sense to the ears, the sound of "cling, clang, clung" coming from the kitchen where the chef"s spatula hit against the iron-metal wok provide the complete five senses experience and a coherent ambiance to a sumptuous Chinese meal.

Qin (2013) noted the Chinese three-meal system with breakfast, lunch, and supper, and how each meal is a balance between "cooked and raw", "solids and liquids", "fan' (base carbohydrates) and 'cai' (dishes)", "meat and vegetable" (p. 37). The continuous balance between the different meals coincides with the Chinese belief that "foods having the 'hot' (Yang) or "cold' (Yin) property which generates different sensations in the human body" (Qin, 2013, p. 36). For the Chinese, food connects the past and present, and identify themselves with their culture (Qin, 2013).

Kirkendall (2010) added that the preeminent tradition of Chinese attitude toward food is one that strives to maintain harmony (balance and stability) in the physical body through promoting bodily health, with those of society and the universe. Kirkendall (2010) mentioned a fourteen-century scholar, Chia Meng, who "provided a literary explanation of the interrelationships of the elements considered vital for the maintenance of good health" (p. 123). The scholar classified hundred of food items into a food system that consists of: (1) the five elements (wood, fire, earth, metal, water); (2) the five organs (gallbladder, small intestines, stomach, large intestines, bladder); (3) the five viscera 


\section{Issues in Information Systems \\ Volume 19, Issue 1, pp. 159-169, 2018}

(liver, heart, spleen, lungs, kidneys); (4) the five emotions (anger, happiness, contemplation, worry, fear); (5) the five seasons (spring, summer, long summer, autumn, winter); and (6) the five flavors (sour, bitter, sweet, spicy hot, salty) (Kirkendall, 2010, p. 123). This knowledge and its elaborate classification created a repository of knowledge management that enabled the recipes of the Chinese cuisine to be socialized and shared from one generation to another.

The origins of Chinese cuisine can be traced back to Emperor Fuxi (c. 2,000 BCE), who taught his subjects to fish, hunt, grow crops and cook (China.org, n.d.). However, cooking first became an art during the Chou Dynasty (1122 249 BCE) in China (China.org, n.d.). For thousands of years, Chinese cuisine has been strongly influenced by the two dominant philosophies of the Chinese culture: Confucianism and Taoism. "Confucius taught that good cooking depends on the blending of various ingredients and condiments rather than the taste of the individual elements" and that "the flavors of the ingredients must be blended with harmony" (China.org, n.d.). Taoism on the other hand, was "responsible for the development of the hygienic aspects of food and cooking" (China.org, n.d.).

Evidence of archeological finds from recently excavated Han tombs reveals valuable details of ancient Chinese food customs. Murals of kitchen activities depict workers - men in the majority — preparing meats, pounding and mashing, drawing water. Paintings of banquets provide clues as to early etiquette and information about food preparation, order of service, table arrangement, and the service of wine and tea, among many other behaviors associated with the preparation and consumption of foods. (Kirkendall, 2010, p. 123)

Chinese cuisine can also be sub-divided into four regional cuisines: (1) Cantonese cuisine; (2) Shandong cuisine; (3) Jiangsu cuisine; and (4) Sichuan cuisine, each representing the Western, Northern, Southern and Eastern part of China. These four regional cuisines are further reclassified as the modern "Eight Cuisines" of Anhui, Cantonese, Fujian, Hunan, Jiangsu, Shandong, Sichuan, and Zhejiang cuisines (Roberts, 2002). These cuisines are differentiated based upon its color, smell, taste, appearance, and the ingredients used within the respective regions.

Chinese gourmets used to argue about whether there should be three, four, six, or eight major high cuisines in China, but the post-modern food scene in China, including Hong Kong and Taiwan today, has obscured all the boundary markers, because of migration, innovation, modern communication, creolization and globalization. (Cheung \& Wu, 2014)

In general, Chinese cuisine can be broadly divided into two areas: the northern and the southern (Kirkendall, 2010). "The northern dishes are heavier and oilier and are based upon wheat or other grains, while the southern rice-based meals include a large variety of meat, fish, and vegetable dishes due to the gentle climate" (Kirkendall, 2010, p. 123). This contrast has been attributed to the differing geographic and climatic conditions, which affected the ingredients, the choice of protein used, the preparation, the presentation and the taste (Kirkendall, 2010).

The earliest confirmed evidence of the Chinese script is in the body of inscriptions on oracle bones from the late Shang dynasty (c. 1200 - 1050 BCE). Later, Emperor Shihuangdi (the first Qin emperor) instituted a standardized system of writing in China (c. 213 BCE). Facilitated by the availability of a system of writing developed in the early days of Chinese civilization, knowledge related to Chinese cuisine has been richly documented. This documentation has enabled Chinese master chefs to effectively transfer knowledge and techniques to their apprentices over time, thus sustaining Chinese cuisine from one generation to the next.

The method of knowledge management practiced within the Chinese culinary world is very much in line with the perspective of Nonaka and Takeuchi: One that is of knowledge creation. The norm practice of starting as a kitchenhelper and moving from an apprentice cook to a cook, and ultimately as a head chef also coincides with the three characteristics of knowledge creation i.e. use of metaphor and analogy, move from personal to organizational knowledge; and enhancing the knowledge through ambiguity and redundancy.

Today, the "landscape of food in China has been transformed dramatically since ancient time" due to "mass media and other forms of mediated communication" (Kuang, 2017, p. 70). In 2010, the recognition of Chengdu (a city in southwest China's Sichuan province known for its wide variety of flavors) as the first UNESCO City of Gastronomy in Asia, has elevated Chinese cuisine and its people on the global stage (Kuang, 2017). Millions can now see the 
artistry of Chinese cuisine via television food programs such as the Food Adventures on the Silk Road, The Delicacies of China, and A Bite of China (Kuang, 2017). China's centuries-old cuisine continues to evolve through the socialization, externalization, combination, and internalization processes described by Nonaka and Takeuchi's spiral of knowledge management.

\section{Russian Cuisine}

Russian food traditions are currently practiced and cultivated not only by the 144 million citizens residing in the Russian Federation, but also by many of the 25-30 million Russians estimated to live outside the borders of the Russian Federation ("Russian Migration 2017"). Russia has experienced five successive, and sizeable, waves of Russian emigration since the Russian Revolution of 1917: The first, caused by the Revolution itself; the second, coming after World War II; the third (mainly Jews) during the 1970s; the fourth (both Jews and non-Jews), in the late 1980s; and a fifth, during the 1990s (Holak, 2014). These were people whom native Russian speakers describe as having relocated to the far abroad. Further contributing to this growing Russian diaspora was the sudden dissolution of the Soviet Union in 1991, which caused 25.2 million Russians living in the near abroad (i.e., one of the newly-independent states that had previously been a Soviet republic) to suddenly find themselves residents of a foreign country (Holak, 2014).

One theme associated with Russian food tradition has been the tendency of ethnic Russians to embrace new dishes and food ingredients. Ask a non-Russian to name the unofficial national dish of Russia, and the immediate response will likely be "borscht". However, borshch, while highly popular with Russians living inside and outside Russia, was originally a Ukrainian dish (Kushkova, 2011). To this day, Russians generally prefer tea to coffee; this is despite the fact that chai (the Russian word for tea) was introduced to Russia relatively late in Russian history, in the early $17^{\text {th }}$ century (Trapeznik 2012). "To Russians, the samovar and tea-drinking are associated with what is quintessentially Russian. Yet until the late nineteenth century, tea-drinking was largely confined to the nobility. Peasants instead typically drank kvass, fermented black bread, and water. The samovar helped 'Russify' the practice of tea-drinking" (Trapeznik, 2012, p. 94). Indeed, the universal popularity of tea drinking has made the distinctively Russian samovar emblematic of Russia and Russian food culture (Trapeznik 2012). Foreign culinary influences have intermittently permeated Russian culture, especially since the $18^{\text {th }}$ century reign of Peter the Great (Павловская, 2016). Illustrating the Russian readiness to embrace new dishes is a 1960 Soviet-era cookbook that features not one, but three distinct, regional recipes for preparing shashlik (kebab): Georgian, Armenian, and Uzbek (Шашлык по-кавказски, Шашлык по-карски, Шашлык по-узбекски) (Кулинария, 1960, p. 154).

In czarist times, certain dishes were eaten, and feasts prepared, in accordance with the Orthodox church calendar and religious holidays, something that Soviet authorities later labored to discourage (Медведева, 2017). Whether under czars or commissars, however, Russians continued to favor soups, cooking from grains, pierogis (dumplings), and drinking kvass, a fermented grain drink (Павловская, Part 2, 2016).

In pre-World War II Russia, canning and pickling were widespread practices, especially in Russian villages, while mass-produced, canned and processed foods were relatively unknown; now-common items like mayonnaise, ice cream, orange juice, and other processed foods were first introduced to the Soviet Union in 1936, after then-Minister of Agriculture Anastas Mikoyan returned from the United States, which he had visited as head of a Soviet delegation (Павловская, Part 2, 2016). Following that visit, tomato juice became popular in Russia, but breakfast cereals never caught on (Павловская, Part 2, 2016).

A second recurring theme in Russian food tradition since Peter the Great has been periodic food scarcity caused by weather, war, politics, or bureaucratic mismanagement. In 1917, it was characteristically Russian for hungry urban workers to demand the Czarist government deliver "bread and peace"; for them, "bread" was synonymous with food, which is not surprising, given the outsized role that flour-based products (such as bread) played in Russian cuisine of the time (Харитонова, 2015). During the Brezhnev era (1964-1982) of the Soviet Union, for example, "food shortages, or 'deficits', reached epic proportions" (Blackledge, 2017, p. 201). These food shortages forced people to develop and perfect a multiplicity of creative everyday practices in order to deal with them" (Blackledge, 2017, p. 201).

A third theme associated with traditional Russian food culture is the often-communal nature of food preparation and consumption, along with their associated rituals. For example, in a 2012 article examining Russian culinary heritage 
and traditions, Julia Ioffe cites Russian food scholar Maksim Syrinkov's commentary regarding the etymological origins of the popular Russian dish solyanka.

Back in the day - say, for a holiday - everyone in the village would bring out whatever they had in the house, put it all in one big pan, and then bake it in the oven... Which is why some people think the dish was originally known as selyanka, not solyanka, from the word selo, which means village. (Ioffe, 2012, p. 56)

The impact of these themes on Russian food culture can be discerned when one examines the history, evolution, and traditions associated with preparing and consuming certain popular Russian dishes. Anna Kushkova (2011) makes a convincing case to award the Russian national dish distinction to Olivier salad, with runner-up status to its slightly more pedestrian "twin brother", vinegret. Although the original Olivier salad was first whipped up by a French chef in the kitchen of pre-revolutionary Moscow's genteel Hermitage Restaurant, Kushkova (2011) writes, it was not until after World War II, in the 1950s and 1960s, that the salad evolved into the "must-have" dish on the table of any self-respecting Russian celebrating a special occasion, holiday, or other festive occasion with family or friends. Kushkova's 27 interviewees, all of whom had all come of age during Soviet times, unanimously agreed that Olivier salad was a "must-have" dish for any special occasion (Kushkova, 2011, p. 50).

In Soviet times, Kushkova (2011) writes, “'Culinary' socialization paralleled socialization per se. While forming their own families or peer groups, people also assimilated culinary standards, which were a condition for the normal functioning of those groups" (p. 51). Although there was no shortage of Soviet cookbooks, "the Olivier salad recipe was passed on by word of mouth and by watching others make it" (Kushkova, 2011, p. 51). In those days, Olivier salad was not something one prepared for a routine family meal; it was the obligatory dish that every family prepared, and expected, for special occasions. In Soviet times, preparation not only required labor in the kitchen, but also forethought and planning. "Olivier salad's essential ingredients are in general not outstandingly complex or costly, although the Soviet period injected a significant degree of variety into the practicalities of acquiring comestibles, introducing the concept of 'short-supply' [defitsitnyi] groceries, which consequently became 'prestige' foods that people went to great and enthusiastic lengths to obtain" (Kushkova, 2011, p. 58). It seems almost quaint in 2018 to imagine planning ahead to acquire a can of peas to make a homemade salad, but such was the reality of Soviet life; canned peas, a key ingredient in Olivier salad, was a delicacy not easily obtainable during Soviet times (Павловская, Part 2, 2016). Once all the ingredients were finally amassed, the labor-intensive preparation of Olivier salad could begin, frequently as an undertaking involving the entire family: children were typically given the task of peeling and slicing the carrots and potatoes, for example (Kushkova, 2011).

Food shortages during the Brezhnev era not only impacted what Russians ate, but also the cultural behaviors and norms surrounding the preparation and serving of food. "The necessity that caused Soviet food-sharing practices resulted in a higher intimacy of social connections and interdependency of the members of society. It also led to specific rituals and unwritten codes of behavior when, for instance, hosts expected specific food gifts from their guests and the guests expected their hosts to provide them with specific foods in return" (Blackledge, 2017, 208).

Presentation and consumption of Olivier salad was often ritualistic. "The Olivier salad was customarily served in whatever 'elegantly festive glass or ceramic' salad bowl was to hand. Some felt they had to use a crystal vase, a sign of luxury and prestige" (Kushkova, 2011, p. 70). Strategically placed in the center of the table and surrounded by other cold appetizers, Olivier salad was traditionally the first food item sampled by those assembled, generally (for the adults, at least) together with vodka; this marked the commencement of the feast (Krushkova, 2011). As Krushkova (2011) explains, "in the minds of the assembled company, the Olivier salad was predominantly a festive dish, the tasting of that dish was the watershed that definitively separated everything 'prefestal' from the festivities themselves, permitting a distancing - a collective distancing - from the everyday and, furthermore, a plunge into another reality, where every mundane care was laid aside" (p. 71). Not only did the initial consumption of Olivier salad mark the commencement of festivities, but the conclusion as well. "Just as the entrance to the celebration had been gradual, as implied by the preparations, so exit from the celebration was not sudden either, and a large role here was played by the Olivier salad. First, the hosts finished it at breakfast, washing it down with whatever had not been drunk on the previous day" (Krushkova, 2011, p. 74).

Russians who grew up in the Soviet Union were similarly well-acquainted with another popular salad called vinegret, a beet-based dish that shared many of the same ingredients (potatoes, brined cucumbers, carrots, and 


\section{Issues in Information Systems \\ Volume 19, Issue 1, pp. 159-169, 2018}

onions) as Olivier salad. While just as "typically Russian" as Olivier salad, vinegret was a more common, mundane dish often consumed as an everyday meal and not regarded as a special occasion dish (Krushkova, 2011). Vinegret originally came to Russia from $18^{\text {th }}$ century France; as first introduced in Russia, vinegret was a dish made with roasted beef, salted cucumbers, capers, onions, and sometimes beets, with a vinaigrette (vinegar-based dressing) poured over it (Павловская, Part 2, 2016). Modern-day Russian vinegret, though, is very different from its French origins. Russians gradually transformed the recipe, which in its Russian form always used beets but not necessarily its other French-inspired ingredients. Originally popular with Russian nobility, by the mid- $19^{\text {th }}$ century, the meatless version became popular with the commoners, largely due to the cost of meat; housewives liked the dish because they could improvise and add leftovers to vinegret (Павловская, Part 2, 2016). A Stalin-era cookbook contained four different recipes for vinegret; even at that late point in time one of those remained true to the original French recipe. By the 1960s, though, the standard Russian vinegret was what it is today: No more meat, no more vinegar (for which Russians substituted readily-available sunflower oil) (Павловская, Part 2, 2016). In Soviet times, people liked vinegret because the ingredients were both inexpensive and readily available and could be served as either a holiday or an everyday dish. In its Russified form, vinegret became popular because its taste complimented not only pickled herring (селёдка/selyodka), a traditional Russian hor d'oeuvre, but also vodka.

In contrast to the French and the Chinese, who take considerable pride in their respective national cuisines, it is not uncommon for Russians, especially those living abroad, to denigrate their own cuisine in comparison to those of other cultures. Generally speaking, the world outside Russia is not very familiar with Russian culture and cuisine, which for them consists of stereotypical vodka and caviar; one Russian food researcher said this is because nonRussians learn about Russian cuisine from émigré authors who are not favorably disposed to the country and culture they left behind (Павловская, Part 2, 2016). Following the fall of the Soviet Union and the establishment of the Russian Federation in 1991, Russians - and Russian palates - rapidly became acquainted with a wide variety of new cuisines and dishes. As had been the case during Peter the Great's time, the culinary window to the world was suddenly opened, and Russians eagerly embraced that which was new and unfamiliar. Olivier salad, a ritual dish of the Soviet era, suddenly found its central location on the festive table challenged by a wide variety of new, and newly-available, foods. Not only increased food options, but also changing tastes and lifestyles seemed to threaten the place of Olivier salad and vinegret; as Krushkova (2011) observes, "Olivier salad is a nightmare for dieters, vegetarians, and advocates of food separation" (p. 73).

To paraphrase Mark Twain, reports of the demise of Olivier salad and vinegret after 1991 were greatly exaggerated. As Holak (2014) notes, "Food, its preparation, and its consumption play a prominent role in the preservation of identity and reconstruction of 'home' in diasporic situations" (p. 188). This may well explain why, fully a generation after the collapse of the former Soviet Union and the easy availability of so many other cuisines and food ingredients, Russians in Russia, and also Russian emigres living abroad, continue to make and share such traditional Russian dishes as Olivier salad and vinegret, and continue the traditions of preparing and serving them in connection with family gatherings and special events, such as New Years. "After adapting to the new market conditions, the Olivier salad has not only retained its old 'clientele' but is also successfully signing up a new client base. Some informants emphasized that children or youngsters in general love it" (Krushkova, 2011, p. 82). The continued appeal of familiar Russian dishes and associated traditions among Russians living outside Russia is consistent with Hofstede's observation that "Food has strong symbolic links with traditions and with group identity, and migrantsespecially those from collectivistic, uncertainty-avoiding cultures - like to retain these links" (p. 411).

Nostalgic sentiments and the longing for a culinary association with "home" are in no way limited to those Russians living outside Russia. Ioffe (2012) relates an anecdote about a middle-aged kitchen manager Ioffe observed in a recently-opened restaurant in Russia that featured traditional Russian dishes familiar to those whose formative years had been spent in the former Soviet Union: "She came across a glass of toplennoe moloko, milk that has sat in a hot pech for several hours until it is the color of crème brûlée and has the faintest suggestion of caramel. She drank it down in a few long gulps. 'Oh, that is so good,' she said, closing her eyes and wiping off the milk mustache with the back of her wrist. 'That's the taste of childhood"” (Ioffe, 2012, p. 63).

\section{SUMMARY}

Food is a core component of culture. The act of gathering and combining ingredients, and the techniques and rituals associated with food preparation, presentation, and consumption create a distinctive cultural experience within the 
context of the culture in which a cuisine is created. "For these ingredients do more than compose an exquisite dish; they transmit a landscape" (Ferguson, 2010). A certain dish may be unique to, and associated with, a particular culture. However, it is not only the particular dish itself, but also the history, rituals, and traditions associated with its preparation, presentation, and consumption, that make those dishes into powerful vehicles for the transfer of cultural knowledge. Therefore, food-related practices and traditions associated with the preparation and consumption of food not only help to define a given culture, but to sustain it and to serve as an effective means for enculturating younger members of the cultural group through the transfer of tacit knowledge via repeated, shared experiences. Through various food-related practices, members of a culture garner lifelong experiences gathering the ingredients for certain dishes, preparing those dishes for consumption, presenting them in certain time-honored ways, and consuming those dishes under certain conditions and in connection with familiar practices and rituals. Through the involvement of friends and family in such food-related traditions, both explicit and tacit cultural knowledge is effectively transferred by various means, thus contributing significantly to the sustainment and perpetuation of the culture itself.

\section{REFERENCES}

Blackledge, O. (2017). Food not eaten: the dialectical image of food in Soviet animation of the Brezhnev era. Studies in Russian \& Soviet Cinema 11(3): 198-211.

Cheung, S., \& Wu, D. Y. (2014). The globalisation of Chinese food: London: Routledge.

China.org. (n.d.). History of Chinese cooking. Retrieved from: http://www.china.org.cn/english/travel/53611.htm

Clark, P. P. (1975). Thoughts for food II: Culinary culture in contemporary France. The French Review, 49(2), 198205.

Durand, R., Rao, H., \& Monin, P. (2007). Code and conduct in French cuisine: Impact of code changes on external evaluations. Strategic Management Journal, 28(5), 455-472.

Ferguson, P. P. (1998). A cultural field in the making: Gastronomy in 19th-century France. American Journal of Sociology, 104(3), 597-641.

Ferguson, P. P. (2003). Writing out of the kitchen: Carême and the invention of French cuisine. Gastronomica, 3(3), 40-51.

Ferguson, P. P. (2006). Accounting for taste: The triumph of French cuisine: University of Chicago Press.

Ferguson, P. P. (2010). Culinary nationalism. Gastronomica, 10(1), 102-109.

Geertz, Clifford (1973). The interpretation of cultures. New York: Basic Books.

Hofstede, G. (1980). Culture's consequences: International differences in work-related values. London: Sage.

Hofstede, G. (1991). Cultures and organizations. Intercultural cooperation and its importance for survival. Software of the mind. London: McGraw-Hill.

Hofstede, G. (2010). Cultures and organizations: Software of the mind. London: McGraw-Hill.

Holak, S. L. (2014). From Brighton beach to blogs: Exploring food-related nostalgia in the Russian diaspora. Consumption Markets \& Culture 17(2): 185-207.

Ioffe, Julia. (2012). The Borscht Belt. New Yorker, 88(9), 56-63. 
Kirkendall, J. M. (2010). Eating history: Chinese American gastronomy in Hawaii. Journal of the Chinese Historical Society of America, 123-132.

Kuang, L. (2017). China's emerging food media: Promoting culinary heritage in the global age. Gastronomica: The Journal of Critical Food Studies, 17(3): 68-80.

Kushkova, A. (2011). At the center of the table. Russian studies in history, 50(1): 44-96.

Minkov, M. (2012). Cross-cultural analysis: the science and art of comparing the world's modern societies and their cultures. Thousand Oaks, CA: Sage.

Morgan, K. K. (n.d.). Does Polanyi’s tacit knowledge dimension exist?

Nonaka, I., \& Takeuchi, H. (1995). The knowledge-creating company. New York: Oxford University Press.

Piwowarski, J. (2013). Ethics of organizational culture as an existing condition of security culture. Science \& Military Journal, 8(1), 41-46.

Polanyi, M. (1966). The tacit dimension. Chicago: The University of Chicago Press.

Qin, J. (2013). Food and binary oppositions in the Chinese meal system. Springer Science and Business Media, $35-$ 39. DOI: $10.1007 / \mathrm{s} 12115-013-9735-0$

Rao, H., Monin, P., \& Durand, R. (2003). Institutional change in Toque Ville: Nouvelle cuisine as an identity movement in French gastronomy. American Journal of Sociology, 108(4), 795-843.

Roberts, J.A.G. (2002) China to Chinatown: Chinese food in the west. Reaktion Books, London.

“Russian migration 2017," UC Davis, Gifford Center for Population Studies, https://gifford.ucdavis.edu/workshop/past/2017-03-23-russian-migration-2017/

Skovira, R. J. (2012). Japanese way, western way: Two narratives of knowledge management. Management, Knowledge and Learning International Conference 2012.

Trapeznik, A. (2012). Samovars: The art of Tula metal workers. New Zealand Slavonic Journal, 46, 91-107.

Vujačić, V. and Kovačević, F. (2016). Gastroscopy and food as cultural practice: The case of Montenegro. Anthropological Notebooks 22(1): 95-105.

Кулинария (1960). Москва. Госторгиздат.

Медведева, 3. А. and О. Э. Васькина (2017). Пищевые запреты в среде российского крестьянства в конце ХІХ - начале XX в. (Food taboos among Russian peasants in the late $19^{\text {th }}$-early $20^{\text {th }}$ centuries). Общество: философия, история, культура (10): 29-32. DOI: 10.24158/fik.2017.10.8

Павловская, А. В. (2016). Из истории русской кухни. Часть 1. Кухня, которую мы «потеряли»? (From the history of Russian cuisine. Part 1. The cuisine we «lost»?) Вопросы диетологии (Nutrition) 6(1): 54-61. 10.20953/2224-5448-2016-1-54-61

Павловская, А. В. (2016). Из истории русской кухни. Часть 2. Страсти по утраченной самобытности. (From the history of Russian cuisine. Part 2. The passion of the lost self-identity.) Вопросы диетологии (Nutrition) 6(2): 61-73. DOI: 10.20953/2224-5448-2016-2-61-74

Харитонова, Е. (2015). Отражение национальных пищевых традиций во фразеологии. Bulletin of Moscow State Regional University 2, 1-10. 